\title{
Development of Pulsed Power Modulator for Induction Synchrotron
}

\author{
Kunio Koseki Member (High Energy Accelerator Research Organization, kunio.koseki@j-parc.jp) \\ Ken Takayama Non-member (High Energy Accelerator Research Organization, ken.takayama@kek.jp)
}

Keywords : pulse, inverter, synchrotron

\section{Introduction}

The concept of an "induction synchrotron" was proposed. The idea was to overcome shortcomings of the conventional $\mathrm{rf}$ synchrotron, in particular the limited longitudinal phase-space available for the acceleration of charged particles - in other words the distribution in energy and position around the ring of the particles being accelerated. Instead of short rf bunches, extremely long bunches, called "super-bunches", are captured and accelerated in the induction synchrotron. A super-bunch confined in the longitudinal direction by a pair of pulsed barrier voltages is accelerated with long induction voltages, as schematically shown in Fig. 1. In this concept, the acceleration of a high-intensity beam is achieved by means of an effective utilization of the longitudinal phase space, which is not available in a conventional rf synchrotron.

Two types of cavities, one for acceleration and the other for longitudinal confinement, are employed and independently energized with pulsed power modulators. Since 2001 , R\&D work on key technologies to realize an induction synchrotron, such as an induction acceleration cell and its driver (pulsed power modulator of current concern), has continued. The induction synchrotron is going to be demonstrated using the KEK $12 \mathrm{GeV}$ proton synchrotron. Pulse voltages have to be generated in a synchronous way with beam circulation in the accelerator ring. A repetition rate of up to $1 \mathrm{MHz}$ is required for the power modulators, assuming a ring of the KEK $12 \mathrm{GeV}$ proton synchrotron, the circumference of which is $340 \mathrm{~m}$.

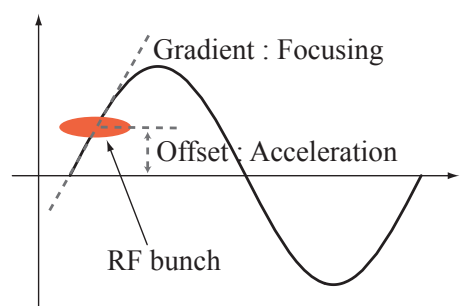

Fig. 1. Conceptual view of the confinement and acceleration in RF synchrotron

\section{Pulsed Power Modulator}

A solid-state pulsed power modulator for an induction synchrotron has been developed. It was operated at a repetition rate of $1 \mathrm{MHzCW}$ with output voltage of $2 \mathrm{kV}$. An acceptable flatness of the output pulse has been achieved by a suficient reduction of the isolation capacitance. The tempreature increase at a surface of a switching element confirms the stable operation of the power modulator.

Recently, prototype devices to realize a induction acceleration in the KEK $12 \mathrm{GeV}$ proton synchrotron, including the pulse modulator with a relatively lower isolation capacitance, which was developed in the present study, were completed. Using these devices, a single proton bunch trapped in a $\mathrm{rf}$ bucket was accelerated from $500 \mathrm{MeV}$ to $8 \mathrm{GeV}$ during $1.9 \mathrm{sec}$.

(a)

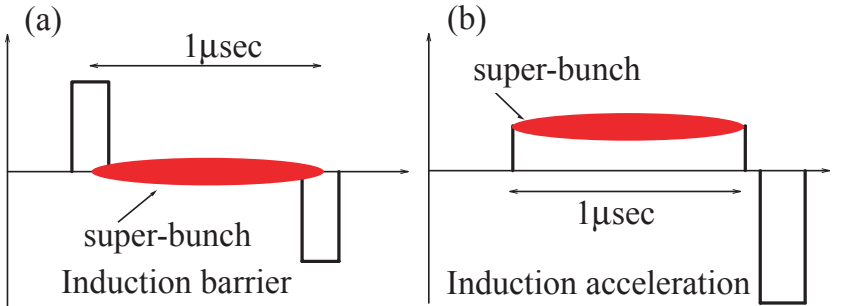

Fig. 2. Conceptual view of (a) particle confinement and (b) acceleration in an induction synchrotron

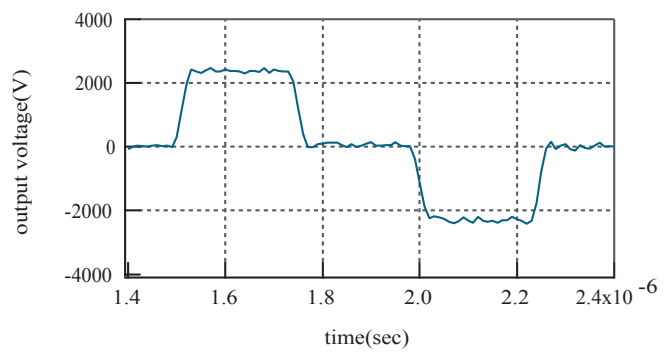

Fig. 3. Output waveform of the developed pulsed power modulator 


\title{
誘導加速シンクロトロンのための $\mathrm{MHz}$ 動作高電圧パルス電源の開発
}

\author{
正 員 小関 国夫* 非会員 高山＼cjkstart健* \\ Development of Pulsed Power Modulator for Induction Synchrotron \\ Kunio Koseki*, Member, Ken Takayama*, Non-member
}

\begin{abstract}
A pulsed power modulator for the POP experiment of an induction synchrotron has been developed. Various difficulties in the development of the modulator, such as enormous power dissipation at a MOSFET, the resonant ringing in the output waveform, the isolation from the ground potential, and the incorrect action of a gate driving circuit, have been discussed and solved. The developed power modulator is installed into the existing accelerator, KEK $12 \mathrm{GeV}$ proton synchrotron. The POP experiment of the induction synchrotron has been successfully conducted. A single RF bunch injected from the $500 \mathrm{MeV}$ booster ring was accelerated to the flat-top energy of $8 \mathrm{GeV}$.
\end{abstract}

キーワード : パルス, MOSFET, インバータ, 高電圧, 誘導加速

Keywords : pulse, MOSFET, inverter, high voltage, induction acceleration

\section{1. まえがき}

次世代の大強度高エネルギー加速器として誘導加速シン クロトロン(Induction synchrotron: IS) ${ }^{(1)}$ の概念が提案され た。この中で, 従来の $\mathrm{RF}$ 電場を用いたビーム進行方向での 荷電粒子の閉じ込め及び，加速方式に代わる新しい手法が 提案された。IS では空洞(2)に発生させたパルス電場によっ て荷電粒子の閉じ込めを行い，スーパーバンチと呼ばれる マイクロ秒にもおよぶ長大なビームを形成する。また，別 途空洞に発生させたフラットトップの長いパルス電場によ って加速を行う。

次章で述べる様に, 従来の RF シンクロトロンでは, 閉じ 込め及び，加速に利用出来る位相空間に限界があり，これ によって得られるビーム強度にも限界があった。IS ではこ の RF シンクロトロンにおける原理的限界を克服し, ビーム 強度を大幅に増強出来る事が期待されている。

IS 実現のためには，シンクロトロンにおけるビームの周 回に同期して連続的にパルス電場を発生させる必要があ る。高エネルギー加速器研究機構(KEK)陽子加速器(PS)で は, 粒子の周回周波数が最大約 $1 \mathrm{MHz}$ にも及ぶため, パル ス電源においても高繰り返し運転が要求される。 $\mathrm{MHz}$ 級動 作を達成したパルス電源としては，現在までに様々なもの が開発されてきた ${ }^{(3)}$ (5)。しかし，ISにおいて要求される高 繰り返し・大電力出力・連続運転を兼ね備えた電源は現在

\footnotetext{
高エネルギー加速器研究機構

厂305-0801 つくば市大穂 1-1

High Energy Accelerator Research Organization,

1-1, Oho, Tsukuba 305-0801
}

までに開発されておらず，パルス電源開発の成否が IS 実現 へ向けた鍵となる。

本論文では, 将来, 飛躍的にビーム強度を増強出来る可 能性を持った IS の実現へ向け, 主要な構成要素, 特に $\mathrm{MHz}$ 級高繰り返し運転を達成したパルス電源の開発について述 べる。さらに，開発されたパルス電源を駆動し行われた第 一次実証試験の結果について報告する。また, 得られた結 果から IS の将来展望にも言及する。

\section{2. 誘導加速シンクロトロンの原理}

1945 年の発明以来, シンクロトロンではビーム進行方向 に対する荷電粒子の閉じ込め及び加速を加速空洞に発生さ せた正弦波電場（RF 電場）によって行ってきた。バンチ重 心にある基準粒子に対して早い位相で空洞に到達した粒子 は, 基準粒子が感じる電場よりも低い電場を感じ, 減速さ れる。また逆に遅く到達した粒子は, 基準粒子に対して相 対的に加速される。リング内での周回を繰り返すうちに, バンチ頭部と尾部では位置の交換をし, 重心周りで振動を する。これがシンクロトロン振動である。つまりシンクロ トロンにおける荷電粒子の閉じ込めには，正弦波電場にお ける勾配が利用されている。また加速電場は, 正弦波のゼ ロ電場からのオフセット分として与えられる (図 1 参照)。

$\mathrm{RF}$ シンクロトロンでは加速に利用出来る位相範囲に制 限があり，必然的にリングに蓄える事の出来る粒子数（ビ 一ム強度）にも限界がある。

しかし，荷電粒子の閉じ込めには必ずしも傾きを持った 電場は必要でない。図 2(a)に示した重心に対して極性の異 
なる電場による閉じ込めも可能である。IS では, 誘導電場 の形でこれを実現する。この場合もバンチ頭部に至った粒 子はバンチ重心に対して減速され，尾部に至った粒子は加 速される。これによって IS における位相安定性が保持され る。加速に関しては，別途用意した空洞に，図 2(b)に示す フラットトップの長い矩形波の形で加速電場を発生させ, これを行う。

これによって, 図 3 に示す様なシンクロトロンのほぼ全 周を覆う長大なバンチ(スーパーバンチ)を形成する事が可 能となり，ビーム強度を大幅に増強する事が出来る。

KEK-PS において，IS の実証試験が計画された ${ }^{(6)}$ 。実証 試験は 3 段階からなり, 第一次実証試験では RF 電場のゼロ 位相（実効加速電場ゼロ）に捕捉された陽子ビームをパル ス電場で加速する。

IS 実現には, 高圧パルス電源(7)(8)の開発が最も重要な課題 である。KEK-PS における粒子の周回周波数は最大 $1 \mathrm{MHz}$ 程度にもなり, パルス電源においてもこれと同期して連続

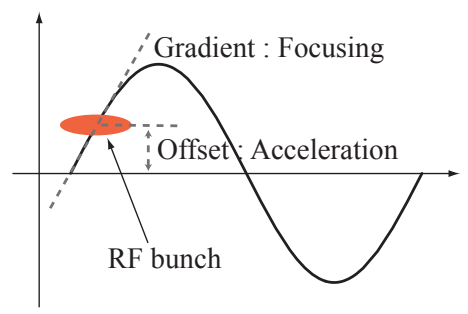

図 $1 \mathrm{RF}$ シンクロトロンにおける閉じ込め・加速原理

Fig. 1. Conceptual view of the confinement and acceleration in RF synchrotron.

(a)

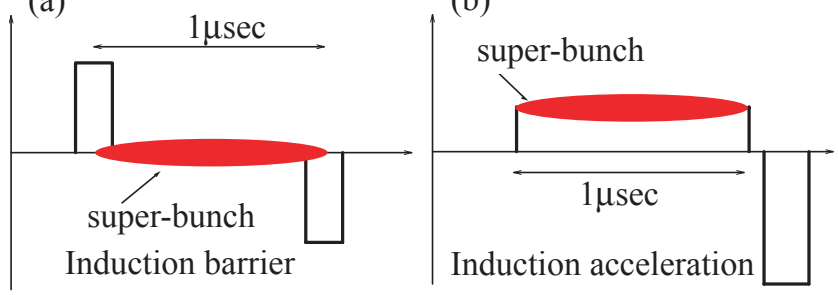

図 2 誘導加速シンクロトロンにおける粒子の
(a)閉じ込め及び,
(b)加速概念図

Fig. 2. Conceptual view of (a) particle confinement and (b) acceleration in an induction synchrotron.

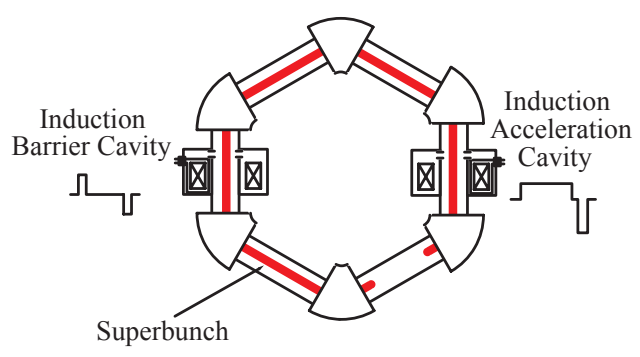

図 3 誘導加速シンクロトロンの概念図

Fig. 3. Conceptual view of an induction synchrotron.
的に高電圧を発生させる必要がある。

\section{3. 高圧パルス電源}

〈3-1〉回路構成 KEK-PS において要求される高圧 パルス電源の仕様を表 1 に纏める。シンクロトロンにおけ る粒子の周回に同期して加速電圧を発生させるため, 繰り 返し周波数は最大 $1 \mathrm{MHz}$ 程度にもなる。また， $15 \mathrm{~kW}$ を超 える平均出力電力が要求される。現在までに, このような 高繰り返し・大電力出力・連続運転を兼ね備えたパルス電 源は開発されておらず, このパルス電源開発の成否が誘導 加速シンクロトロン実現へ向けた鍵である。

パルス電源はフルブリッジ回路で構成される (図 4 参照)。 各スイッチングアームは高電圧出力を達成するため, 7 直列 のMOSFET によって構成される。

〈3・2〉素子選定 IS 用高圧パルス電源では, $\mathrm{MHz}$ 級繰り返し動作を連続的に行うため, 高速, 低損失素子を 選定する事が重要である。表 2 に採用した MOSFET (DE475-102N20A)の基本性能を示す。また比較のため, 一 般的に利用されている素子(2SK2611)についても併記する。 採用した素子は $\mathrm{MHz}$ 動作にも耐え得る高速性能を有し, 且 つ一般的な素子と比較して一桁小さな熱抵抗を実現してい

表 1 パルス電源の出力パラメタ

Table. 1 Parameters of the pulsed power modulator.

\begin{tabular}{|c|c|}
\hline Repetition frequency & $668-877 \mathrm{kHz}$ \\
\hline Output voltage & $2 \mathrm{kV}$ \\
\hline Output current & $16.7 \mathrm{~A}$ \\
\hline Pulse width & $250 \mathrm{nsec}$ \\
\hline
\end{tabular}

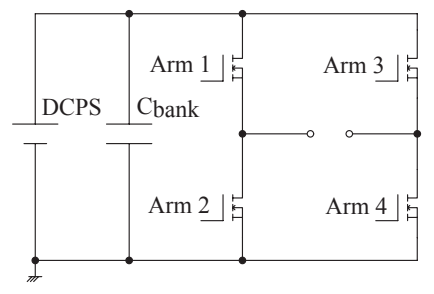

図 4 パルス電源の回路構成

Fig. 4. Circuit schematic of the pulse power modulator.

表 2 採用した MOSFET の特性表

Table 2. Parameters of the employed MOSFET.

\begin{tabular}{|c|c|c|}
\hline & DE475-102N20A & $2 \mathrm{SK} 2611$ \\
\hline $\mathrm{V}_{\mathrm{DSS}}$ & $1000 \mathrm{~V}$ & $900 \mathrm{~V}$ \\
\hline $\mathrm{I}_{\mathrm{D}}$ & $20 \mathrm{~A}$ & $9 \mathrm{~A}$ \\
\hline $\mathrm{Ron}_{\mathrm{t}}$ & $0.6 \mathrm{ohm}$ & $1.1 \mathrm{ohm}$ \\
\hline $\mathrm{t}_{\mathrm{r}}$ & $5 \mathrm{nsec}$ & $25 \mathrm{nsec}$ \\
\hline $\mathrm{tf}_{\mathrm{f}}$ & $8 \mathrm{nsec}$ & $20 \mathrm{nsec}$ \\
\hline $\mathrm{Q}_{\mathrm{g}}$ & $160 \mathrm{nC}$ & $58 \mathrm{nC}$ \\
\hline $\mathrm{R}_{\mathrm{th}}$ & $0.08 \mathrm{~K} / \mathrm{W}$ & $0.833 \mathrm{~K} / \mathrm{W}$ \\
\hline
\end{tabular}




\section{るのが特徴である。}

実証試験において要求される $\mathrm{MHz}$ 級繰り返し動作を連 続的に安定に行うためには，素子における発熱量の見積も り及び，冷却設計が非常に重要となる。

パルス電源開発に際し，素子における損失を見積もった。 出力電圧 $2 \mathrm{kV}$ における導通損失は,

$$
P_{O N}=\frac{1}{T} \int_{0}^{T} R_{O N} I_{D}^{2} d t=41.8(\mathrm{~W})
$$

となる。ただし， $T$ は繰り返し周期， $R_{O N}$ はオン抵抗， $I \mathrm{D}$ はドレイン電流である。ここで，オン抵抗 $R_{O N}=0.6 \mathrm{ohm}$ (一 定)， $I_{D}=16.7 \mathrm{~A}$ （ピーク電流值）とした。またスイッチン グ損失は,

$$
P_{S W}=\frac{1}{T} \int_{0}^{T} V_{D S} I_{D} d t=55(\mathrm{~W})
$$

となる。だたし， $V_{D S}$ はドレインーソース間電圧である。 ここで, $V_{D S}=440 \mathrm{~V}$ とし, 電圧及び, 電流の立ち上がり／下 がり時間を 30nsec とすると，(2)式より，55W のスイッチ ング損失が導かれる。MOSFET における総損失は(1)式と (2)式の和であるから，96.8W となる。

採用した DE475-102N20A は面実装素子であり，PCB と 冷却板とで素子を挟み込む事によって, 約 $0.3 \mathrm{~K} / \mathrm{W}$ の熱抵抗 を達成出来る事が確認されている。これによって十分な冷 却能力が得られる見込みを得た。

$\langle 3 \cdot 3\rangle$ 寄生共振と所望平坦度 前述の通り, IS 実証 試験に使用されるパルス電源では， $1 \mathrm{MH}$ にもおよぶ高繰り 返し運転が要求される。このため数十ナノ秒以下という急 峻な立ち上がり及び，立下り時間が出力パルス電圧に対し て要求される。MOSFET ドレイン - ソース間にはオフ時,

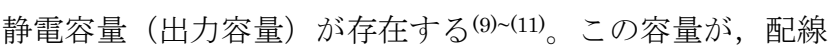
による寄生インダクタンスと結合し，共振回路を形成する。 直列結線された MOSFET によるスイッチングアームの持 つ合成容量を $C_{2,3}$, オン抵抗を $R_{1,4}$, 寄生インダクタンスを $L_{1-4}$ とすると, パルス電源の周波数応答特性は( 3 )式によっ て表現される（図 5 参照)。

$$
G(\omega)=\frac{V_{\text {out }}}{V_{\text {in }}}=\frac{L_{2} C_{2} \omega^{2}-1}{\left(L_{1}+L_{2}\right) C_{2} \omega^{2}-1-j \omega R_{1} C_{2}} \frac{Z_{\text {cavity }}}{R_{4}+Z_{\text {cavity }}+j \omega L_{4}}
$$

ここで, Arm3 は前後でその状態が変化しないので, この 影響を無視した。（3)式から周波数領域（図 6）及び，時間 領域（図 7）における出力電圧特性が各々得られる。誘導加 速シンクロトロンでは, 図 7 に示す様な振動が加速電圧に 重畳されると，バンチに含まれる荷電粒子分布が著しく悪 化し，ビーム不安定性等の深刻な問題を引起す事が予想さ れており，10\%以下の平坦度が望ましい(12)。ここで，振動 電圧のピーク值と設定パルス電圧波高との比を平坦度とし て定義した。

図 8 に初期の試作機における出力波形を示す。パルス立

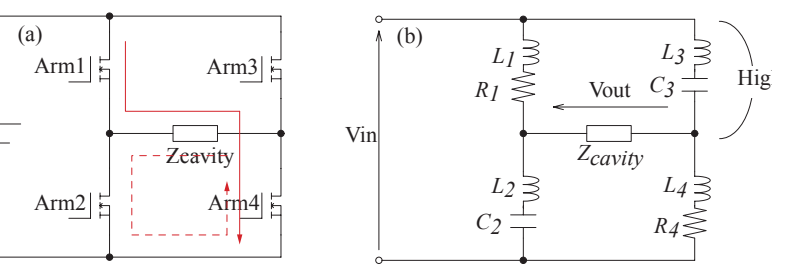

図 5 パルス電源の等価回路

Fig. 5. Equivalent circuit model of the pulsed power modulator.

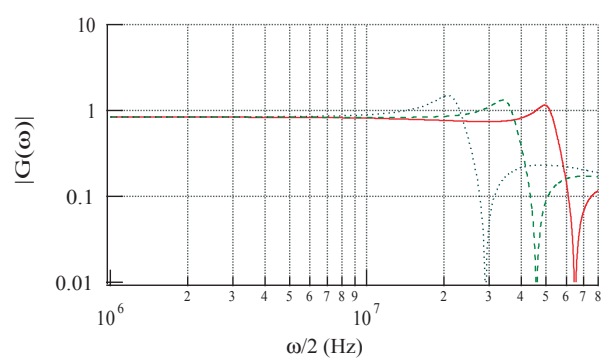

図 6 周波数領域における出力電圧特性

Fig. 6. Output waveform in the frequency domain for a self-inductance of $300 \mathrm{nH}$ with arm capacitances of $20 \mathrm{pF}$ (solid), $40 \mathrm{pF}$ (dashed) and $100 \mathrm{pF}$ (dot).

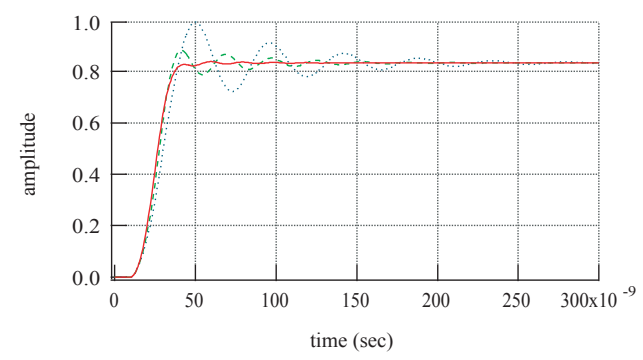

図 7 時間領域における出力電圧特性

Fig. 7. Output waveform in the time domain for a self-inductance of $300 \mathrm{nH}$ with arm capacitances of 20 $\mathrm{pF}$ (solid), $40 \mathrm{pF}$ (dashed) and $100 \mathrm{pF}$ (dot).

ち上がり時間は約 $50 \mathrm{nsec}$ と比較的緩やかであるにも拘らず 平坦度は約 $75 \%$ であり, 平坦度改善が大きな課題となった。 平坦度を改善するためには，アーム内に存在する容量の 低減と配線による寄生インダクタンスの低減が効果的であ る。パルス電源内配線を図 $9(\mathrm{a})$ に示す長方形配線でモデル 化すると, これによるループインダクタンス Lloop は(4)式 で表現される。

$$
\begin{aligned}
L_{\text {loop }}= & \frac{\mu}{\pi}\left\{-a \log \left(a+\sqrt{a^{2}+b^{2}}\right)-b \log \left(b+\sqrt{a^{2}+b^{2}}\right)\right. \\
& \left.+(a+b) \log \left(\frac{2 a b}{r}\right)+2 \sqrt{a^{2}+b^{2}}-\frac{7}{4}(a+b)\right\}
\end{aligned}
$$

これより, パルス電源試作機には, 約 $1.5 \mu \mathrm{H}$ 程度の配線 インダクタンスの存在が明らかになった。また，(4)式より 


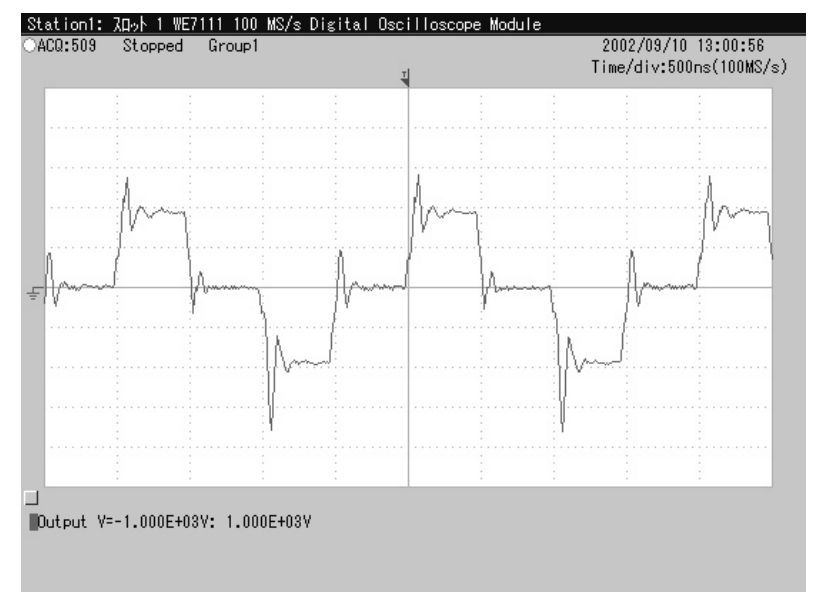

図 8 パルス電源試作機における出力電圧波形

Fig. 8. Output pulse waveform of the proto-type power modulator.

(a)

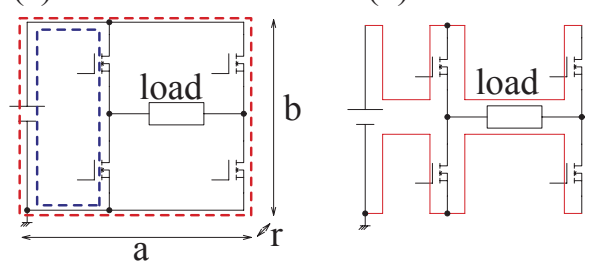

図 9 パルス電源内配線モデル

Fig. 9. Conceptual view of the wiring pattern.

$a$ 又は $b$ の何れかを極小にする事で, 配線インダクタンスを 大幅に低減出来る事も併せて分かった。

具体的には図 9(b)に示す様に，配線ループによって囲ま れる面積を低減する事によってインダクタンスの低減を図 つた。この手法によりインダクタンスを $300 \mathrm{nH}$ 程度にまで 低減する事が出来た。得られた出力電圧波形は後の章で示 す。

〈3.4〉 電圧分布 多数の素子を直列構成したスイッ チングアームでは，各素子に印加される電圧を均一にする 事が重要な問題である。特に，本電源では $1 \mathrm{MHz}$ という周 期でオン，オフを繰り返すため，アーム内の静電容量分布 が電圧分布に大きな影響を及ぼす。MOSFET を駆動する電 力は絶縁型 DC-DC コンバータによって供給する。コンバー 夕には入出力間容量 (絶縁容量) が各 MOSFET のソース電 位と接地電位との間に存在する。これによって, 各 MOSFET のドレインーソース間では, オフ時印加される電 圧に不均一を生じる。この現象は絶縁容量と素子容量でモ デル化出来，絶縁容量を低減する事で改善される。

図 10 及び，図 11 に 5 直列した MOSFET の各ドレイン ーソース間電圧の測定結果を示す。なお，スイッチングア 一ムへの印加電圧は $1 \mathrm{kV}$ である。絶縁容量を $81 \mathrm{pF}$ から $15 \mathrm{pF}$ へと極小にする事で，各 MOSFET に印加される電圧 の分布が均一化された。また，測定結果と計算結果が良く 一致する事から,この現象は MOSFET の容量と絶縁容量で

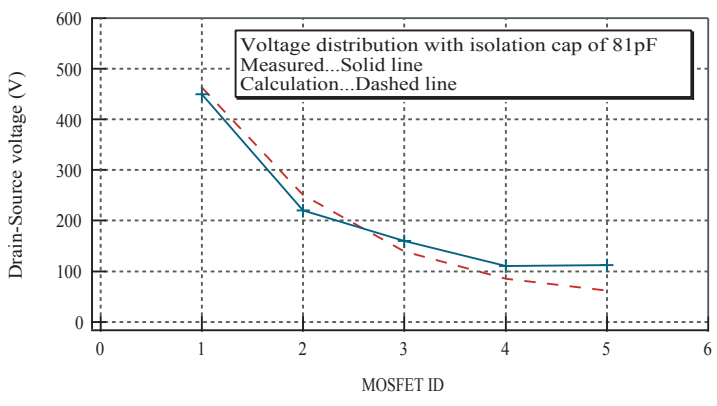

図 105 直列結線された各 MOSFET におけるドレインー ソース間電圧の測定值（実線）及び解析值（点線） (コンバータ入出力間容量 $81 \mathrm{pF}$ )

Fig. 10. Measured (solid-line) and calculated (dashedline) drain-source voltages of each MOSFET in 5 series composition with the charging voltage of $1 \mathrm{kV}$ and the isolation capacitances of $81 \mathrm{pF}$.

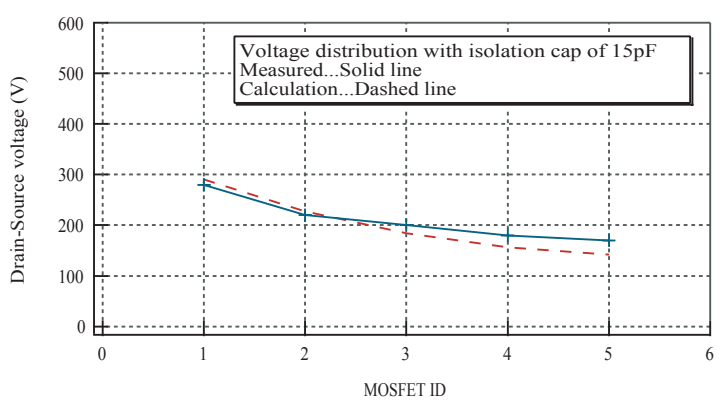

図 115 直列結線された各 MOSFET におけるドレインー ソース間電圧の測定值（実線）及び解析值（点線） (コンバータ入出力間容量 $15 \mathrm{pF}$ )

Fig. 11. Measured (solid-line) and calculated (dashedline) drain-source voltages of each MOSFET in 5 series composition with the charging voltage of $1 \mathrm{kV}$ and the isolation capacitances of $15 \mathrm{pF}$.

説明出来る事が判明した。

〈3.5〉誤動作 MOSFET を高速且つ安定に動作さ せるためには，素子及び周辺回路の持つ寄生インダクタン スの影響を考慮する必要がある(13)。特にソース電極に存在 するインダクタンスの影響を検証するため, 図 12 に示す等 価回路を用いた。

MOSFET のパッケージには電極構造の非対称性等から くる寄生インダクタンス $L_{g}$ 及び $L_{s}$ が存在する。特に高速ス イッチング動作時には，ソース電極に寄生するインダクタ ンスの影響が深刻である。スイッチング動作時，急峻な $d I_{d} / d t$ が $L_{s}$ に流れ込む事によって，ゲート電圧は負帰還を 受ける。これをシミュレーションによって確認したのが, 図 13 であり，実験的に再現したのが図 14 である。 ゲートをオフにするタイミングでは，ゲート閾值電圧を超 える正電圧が $L_{S}$ に誘導され，これによってオン状態へ引き 戻される。ゲートがオンすると, 負電圧が $L_{s}$ に誘導され再 


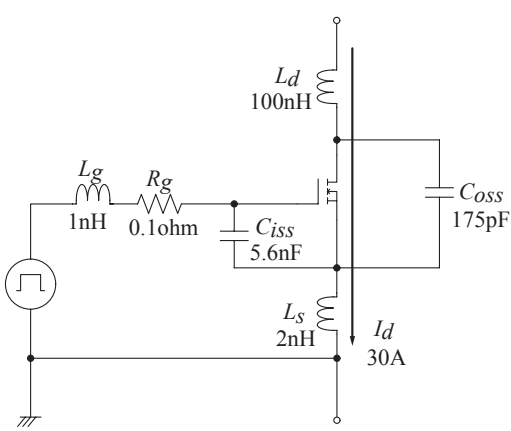

図 12 ゲート駆動時の等価回路図

Fig. 12. Equivalent circuit schematic of the gate driving circuit.

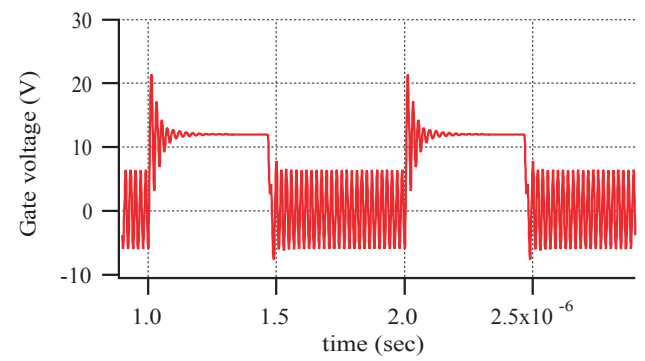

図 13 ゲート電圧波形（シミュレーション）

Fig. 13. Gate voltage waveform by a circuit simulation.

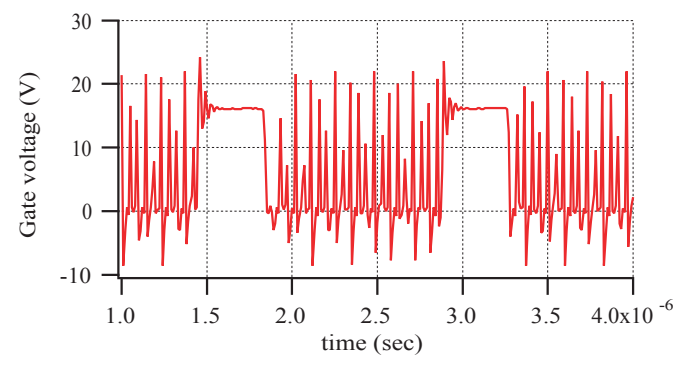

図 14 ゲート電圧波形（実測）

Fig. 14. Gate voltage waveform by a measurement.

びオフ状態へと戻る。これらの状態が繰り返され, 出力電 圧においても発振が観測された。

MOSFET のゲート立ち上がり・立下り時間はゲート容量 $C_{i S S}$ とこれに直列に存在するインピーダンス $\left(L_{g}, R_{g}\right)$ で決定 される。ゲート抵抗 $R_{g}$ を大きくする事によって発振を抑え られる事は言うまでもないが，スイッチング時間が長くな り損失の増大を招く。そこで数通りの抵抗值における, 発 振及びスイッチング時間の相関を実験的に検証し，ゲート 抵抗 $10 h m$ を採用した。またこの抵抗によって前述の発振 を抑え, 安定動作を確保した。

$\langle 3 \cdot 6\rangle$ 連続通電試験 抵抗負荷 $115 \mathrm{ohm}$ を用い，連 続通電試験を行った。この際の出力電圧波形を図 15 に示す。 電源内配線の低インダクタンス化により，30nsec という急 峻なパルスの立ち上がりにも拘らず $5 \%$ の平坦度を達成し

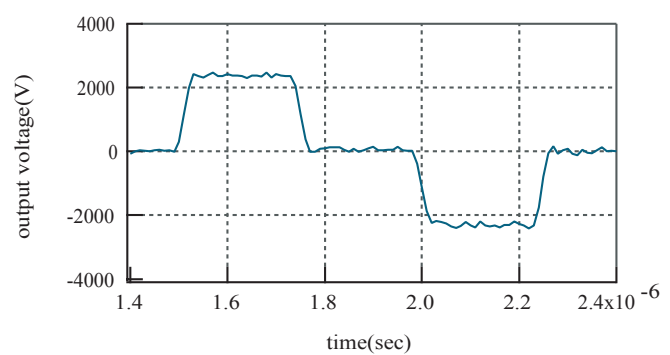

図 15 開発されたパルス電源における出力電圧波形

Fig. 15. Output waveform of the developed pulsed power modulator.

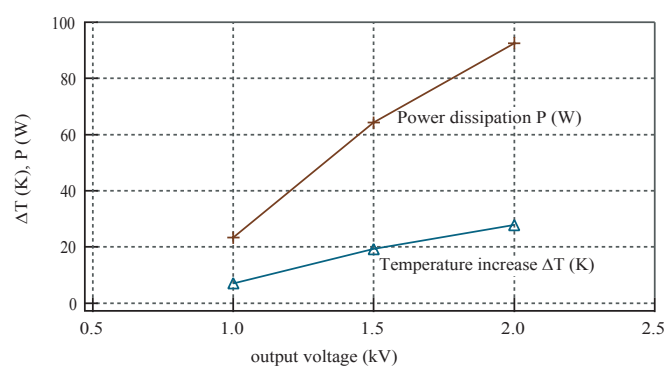

図 16 MOSFET の表面温度及び，発熱量

Fig. 16. Measured surface temperature of the MOSFET and the power loss.

た。

連続運転において最も重要となるのが, MOSFET におけ る発熱である。充電電圧 $2 \mathrm{kV}$ における観測された素子表面 温度を図 16 に示す。また, 冷却系の熱抵抗から推測した発 熱量も併せて示す。

観測された発熱量約 $90 \mathrm{~W}$ は, 先に示した予測とほぼ一致 し, 且つ, 温度上昇も $30 \mathrm{~K}$ 程度であった事から MOSFET の安定動作が確認されたと言える。

\section{4. 実証試験}

一連の研究を経て開発されたパルス電源を駆動して, KEK-PS において誘導加速シンクロトロンの第一次実証試 験が行われた。前段加速器から入射された $500 \mathrm{MeV}$ の陽子 ビームを RF 電場のゼロ位相に捕捉し, 誘導加速空洞に発生 させたパルス電場によって $8 \mathrm{GeV}$ にまで加速した(14)。

\section{5. まとめ}

誘導加速シンクロトロンの第一次実証試験に用いられ る, 高電圧パルス電源を開発した。出力電圧 $2 \mathrm{kV}$, 繰り返 し周波数 $1 \mathrm{MHz}$ における連続通電試験において安定動作を 確認した。

本研究において開発されたパルス電源を用い, 円形加速 器では世界に先駆け, 誘導加速電場のみによる陽子の加速 を行った。前段加速器から入射された $500 \mathrm{MeV}$ の陽子ビー ムを $8 \mathrm{GeV}$ にまで加速した。

誘導加速シンクロトンでは RF 加速装置を誘導加速装置 
に置き換えるだけで，ビームの増強が期待出来，既存の $\mathrm{RF}$ シンクロトロンへの適用が検討されている。これによると， ビーム強度を 2 倍以上に増強出来るが事が試算されており, 1 台の誘導加速シンクロトロンで 2 台分以上の RF シンクロ トロンに相当するビームの供給が期待される。

癌治療等に利用されている小型シンクロトロンでは, リ ング周長が短いため，粒子の周回周波数が 5 から $10 \mathrm{MHz}$ である。パルス電源においてさらなる高繰り返し運転が実 現できれば，これらの小型シンクロトロンへの適用も可能 となる。

\section{謝 辞}

本研究におけるパルス電源開発に当たり，故木代純冕教 授 $(\mathrm{KEK})$, 徳地明氏(ニチコン草津株式会社)及び，和気正 芳助教授 (KEK) には多くの助言を頂いた。KEK 陽子加速 器グループの方々には様々な協力をして頂いた。ここに感 謝申し上げます。

(平成 17 年 6 月 21 日受付, 平成 17 年 10 月 6 日再受付)

\section{文献}

(1) K. Takayama and J. Kishiro : "Induction Synchrotron" Nucl. Inst. Meth., Vol.A 451, p.304 (2000)

(2) K. Torikai, Y. Arakida, S. Inagaki, J. Kishiro, K. Koseki, E. Nakamura, K. Takayama, T. Toyama, and M. Wake : "Design Study of $1 \mathrm{MHz}$ Induction Cavity for Induction Synchrotron", Proc. of PAC2003, J. Chew, Ed., Institute of Electrical and Electronic Engineers, Piscataway, N.J, 2003, TPPB079 (2003)

(3) J. A. Watson, et al. : "A Solid-State Modulator for High Speed Kickers", Proc. of PAC2001 (2001)

(4) E. G. Cook, et al, : "Review of Solid-State Modulators", Proc. of XX International Linac Conference (2000)

(5) M. Watanabe : PhD. Thesis, TIT (2001)

(6) K. Takayama, Y. Arakida, S. Igarashi, D. Iwashita, J. Kishiro, K. Koseki, E. Nakamura, M. Sakuda, H. Sato, Y. Shimosaki, M. Shirakata, K. Torikai, T. Toyama, M. Wake, K. Horioka, and M. Shiho : "A POP Experiment Scenario of Induction Synchrotron at the KEK 12GeV-PS”, Proc. of PAC2003, J. Chew, Ed., Institute of Electrical and Electronic Engineers, Piscataway, N.J, 2003, TPPB093 (2003)

(7) K. Koseki, K. Takayama, and J. Kishiro : "High Repetition Rate Pulse Generator for Induction Synchrotron”, KEK-Proceedings 2002-30, K. Takayama, Ed., High Energy Accelerator Research Organization, Tsukuba, 2002, p.82 (2002)
(8) K. Koseki, Y. Arakida, S. Igarashi, S. Inagaki, J. Kishiro, E. Nakamura, H. Sato, Y. Shimosaki, M. Shirakata, K. Takayama, K. Torikai, T. Toyama, and M. Wake : "R\&D Works on $1 \mathrm{MHz}$ Power Modulator for Induction Synchrotron", Proc. of PAC2003, J. Chew, Ed., Institute of Electrical and Electronic Engineers, 2003, ROAC011, Piscataway, N.J (2003)

(9) M.Miura, et al : "Circuit-Simulation Technics and MOSFET Modeling", ISBN 4-89808-040-5

(10) G.Massobrio and P.Antognetti : Semiconductor Device Modeling with SPICE, Second edition, ISBN 0-07-134955-3

(11) A.S.Grove : Physics and Technology of Semiconductor Devices, ISBN 4-274-13018-5

(12) K. Koseki : PhD. Thesis, The Graduate University for Advanced Studies (2004)

(13) Derected Energy, Inc. Technical Note: "The destructive effects of Kelvin leaded packages in high speed, high frequency operation", http://www.ixysrf.com/design.html

(14) K. Takayama, K. Koseki et al., : "Observation of the Acceleration of a Single Bunch by Using the Induction Device in the KEK Proton Synchrotron", Phys. Rev. Lett., Vol.92, No.15 (2005)

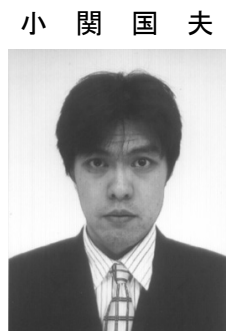

（正員） 1975 年 2 月 22 日生まれ。 1998 年 3 月筑波大学自然学類卒業。米国ブルックヘブン 国立研究所において TOF 検出器の開発に従 事。2005 年 3 月総合研究大学院大学高エネル ギー加速器科学専攻修了。誘導加速シンクロト ロンのための高電圧パルス電源の開発に従事。 現在, 大強度陽子加速器計画(J-PARC)における 電磁石及び電源の研究開発に従事。高エネルギ 一加速器研究機構研究機関研究員。工学博士。

高 山 健 （非正員） 1951 年 2 月 18 日生まれ。 1980 年

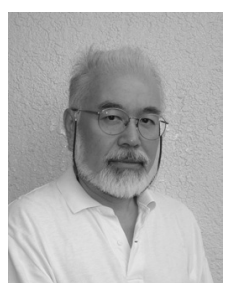
東北大大学院理学研究科原子核理学専攻修了。 同年米国フェルミ国立加速器研究所研究員。反 陽子蓄積リングの設計とハドロンビーム力学 の研究に従事。1983 年高エネルギー物理研究所 助手。電子陽電子衝突型加速器卜リスタン建設 に参加後，マイクロ波自由電子レーザーの開発 に従事。ヒューストン大学, ローレンスバーク レー研究所の客員研究員等を経て, 現在高エネルギー加速器研究機 構加速器機構教授。学術創成研究プロジェクト「誘導加速シンクロ トロンの実証研究」代表。理学博士。 